\title{
Filozofia w obronie tradycji klasycznego racjonalizmu politycznego
}

DOI 10.35757/CIV.2015.17.16

Romuald Piekarski, Makiawelizm, patologia ducha, sacrum i polityka. Eseje z filozofii politycznej, Spółdzielczy Instytut Naukowy, G. Bierecki, Sopot 2015, ss. 354.

Książka Makiawelizm, patologia ducha, sacrum i polityka. Eseje $z$ filozofii politycznej Romualda Piekarskiego to zbiór poruszających i przenikniętych erudycją tekstów, będących swoistymi ćwiczeniami z filozofii politycznej. Diagnozując współczesny nihilizm i nieobecność sacrum w kulturze, autor osia swych rozważań czyni myśl Niccolò Machiavellego, ukazując późniejszy nurt destrukcyjny (Hobbes, Kant, Nietzsche) w przeciwstawieniu do wcześniejszego nurtu odpowiedzialnych dociekań nad rozumnościa praktyczna (Arystoteles, Cyceron, Tomasz z Akwinu, Edmund Burke). Łącząc konserwatywny szacunek do cnoty mądrości i roztropności z republikańskim rozumieniem państwa i uprawiania polityki, autor proponuje nowe spojrzenie na problemy nowoczesności, zwiazane $z$ globalizacja, odpowiedzialnością w życiu publicznym i rola elit intelektualnych. Odwołuje się w tych rozważaniach do najważniejszych myślicieli naszych czasów: Maksa Webera, Karla Jaspersa, Hannah Arendt, Erica Voegelina, Leo Straussa i Alasdaira MacIntyre'a.

I tak część pierwsza przedstawia istotny sens przewrotu w filozofii politycznej, dokonanego w myśli Machiavellego. Piekarski dostrzega tu źródła nowożytnego nihilizmu, który doszedł w pełni do głosu w twórczości Nietzschego. To, co zrobił Machiavelli w filozofii polityki, Nietzsche powtórzył w etyce i filozofii moralnej. Już u Machiavellego bowiem dostrzegamy gwałtowną nienawiść do chrześcijaństwa i powrót do cnót pogańskich. Toteż jego pochwała republiki rzymskiej skupia się na cnotach doczesnych: strachu, 
sławie, sile, harcie ducha i zadowoleniu $z$ tego świata. Wyśmiewa zaś cnoty chrześcijańskie, takie jak pokorę, miłość, poświęcenie, szlachetność - uznając je za cnoty podejrzliwe wobec świata. Te ostatnie Nietzsche uznał za cnoty miękkie, proponujac ich rozkład i zastapienie przez twarde cnoty siły, destrukcji, rozprzężenia i twórczego chaosu. Stąd też głoszony przez Nietzschego nihilizm egzystencjalistyczny ma przedłużenie w nihilizmie politycznym Hitlera, z jego zasada absolutnego wodzostwa. Źródła tej zasady tkwia w poradach, jakich udziela Machiavelli w swoim Księciu. Dlatego Piekarski, podązając za interpretacjami Machiavellego powstałymi w szkole Leo Straussa (Harvey Mansfield) stwierdza, że autora Księcia trzeba uznać za pierwszego nowożytnego „nauczyciela zła”, będącego jednocześnie ojcem nowożytnego nihilizmu, zarówno indywidualistycznego, jak i politycznego. Można tylko dopowiedzieć, że taka interpretacja myśli Machiavellego nie jest jedyna, i może szkoda, że autor nie odniósł się krytycznie do głównej interpretacji konkurencyjnej, głoszonej przez czołowych przedstawicieli szkoły historii idei z Cambridge (Quentin Skinner, John Greville Agard Pocock). Autorzy ci kontekstualizują twórczość Machiavellego, ukazujac, w jaki sposób jego poglądy były wynikiem odpowiedzi na konkretne problemy ideologiczne, polityczne, społeczne i moralne, które wpływały na życie ludzi w republikach włoskich na poczatku XVI wieku. Pozwala to na ukazanie, jakimi drogami myśl Machiavellego kształtowała nowożytna tradycję republikańską $\mathrm{w}$ okresie renesansowego humanizmu i wpłynęła na poglądy wczesnoliberalne w XVII wieku w Anglii.

W rozdziale drugim zatytułowanym Rozum praktyczny. Cnoty $i$ tradycja głównym bohaterem jest Alasdair MacIntyre i jego koncepcja etyki cnoty, zawarta w głośnej książce After Virtue. Piekarski skupia się jednak przede wszystkim na cnotach politycznych, a zwłasza na cnocie roztropności, analizujac, w jaki sposób można opisać ja w kontekście działania rozumu praktycznego lub racjonalności praktycznej. W próbach jej rekonstrukcji u Świętego Tomasza $z$ Akwinu posiłkuje się pracami zapomnia- 
nego już nieco, a przecież tak znakomitego tomisty, jakim był Jacek Woroniecki. Następnie, w poszukiwaniu źródeł dzielności i roztropności, zwraca się do Arystotelesa, a opisując granice rozumu praktycznego, nawiązuje do myśli Edmunda Burke'a. Całość rozważań ujęta jest w kontekście odnowionej przez MacIntyre'a tradycji tomizmu arystotelesowskiego. Warto podkreślić, że Piekarski, postulując powrót do cnoty roztropności jako podstawowej cechy rozumu politycznego i rozumu praktycznego, nie sytuuje jej w macintyre'owskim przeciwstawieniu pomiędzy Arystotelesem i Nietzschem, lecz pomiędzy Arystotelesem i Kantem. Wynika to $z$ tego, że spór starożytnych $z$ nowożytnymi o znaczenie cnót politycznych dotyczy właśnie znaczenia, jakie nadawali pojęciu rozumu praktycznego dwaj najważniejsi antagoniści, Arystoteles i Kant. Piekarski odbiega od proponowanej przez MacIntyre'a konfrontacji pomiędzy Arystotelesem i Nietzschem, gdyż w tym wypadku dotyczy ona tylko indywidualnego znaczenia, jakie nadajemy etyce i samej cnocie. Stąd też Nietzsche jako propagator „przewartościowania wszystkich wartości” jest największym antagonista Arystotelesa. Jednak w wypadku roli i znaczenia cnoty w wymiarze politycznym za największego antagonistę Arystotelesa może być uznany Kant, propagator autonomicznego rozumu praktycznego, który działa bez żadnego związku $z$ rozumem teoretycznym. Odrzucając nowożytną koncepcję rozumu, będąca źródłem nowożytnego liberalizmu, Piekarski opowiada się całkowicie po stronie Arystotelesa, uznając go za niedościgłego mistrza cnót politycznych.

W części trzeciej, zatytułowanej Patologia ducha. Sacrum i polityka, czytelnik znajdzie cztery eseje poświęcone nieobecności sacrum we współczesnej kulturze i propozycji jego przywrócenia na drodze odnowy teologii politycznej. Analizujac myśl polityczna Burke'a - myśliciela, który w okresie terroru rewolucji francuskiej, dostrzegał makiaweliczne skutki polityki nowożytnej - Piekarski rekonstruuje źródła brytyjskiego konserwatyzmu w XVIII wieku. Broni Burke'a przed zarzutem antyracjonalizmu i wskazuje, że w jego myśli można się doszukać takiej koncepcji rozumu, któ- 
ra nie jest wąsko oświeceniowa i abstrakcyjna, lecz przeciwnie, jest zwiąana $z$ doświadczeniem i przejawia się $\mathrm{w}$ zwyczajach, praktykach oraz instytucjach konkretnego społeczeństwa. I szkoda tylko, że autor nie nawiązał do Russella Kirka, może najbardziej burkowskiego wśród dwudziestowiecznych konserwatystów, bo wtedy łatwiej byłoby mu obronić tezę, że ład i porządek społeczny jest prawdziwym gwarantem stabilnego funkcjonowania społeczeństwa, chroniacym najlepiej przed chaosem, jaki niesie gwałtowna zmiana będąca skutkiem rewolucji.

W kolejnych esejach Piekarski zwraca się do analizy dwudziestowiecznego totalitaryzmu nazistowskiego $z$ perspektywy degrengolady niemieckich elit intelektualnych, które nie były $\mathrm{w}$ stanie nie tylko wyrazić moralnego oburzenia, ale nawet poprawnie zdiagnozować idolatrii totalitarnej Trzeciej Rzeszy. Dla czytelnika polskiego jest to o tyle ciekawe, że w rodzimych badaniach dosyć szeroko i wielostronnie przeanalizowano motywy zaangażowania intelektualistów w sowietyzm i opowiedzenia się po stronie ideologii komunistycznej, natomiast ciagle mało znane sa motywy intelektualistów niemieckich flirtujących $z$ nazizmem i stojących po stronie Hitlera. Piekarski odwołuje się przy tym głównie do badań Erica Voegelina, który tropiąc elementy gnostyckie w polityce niemieckiej, wskazywał, że zanik doświadczenia sacrum zaowocował kultem bożków, które legitymizowały relatywizm i nihilizm w polityce niemieckiej. Paranoiczno-makiaweliczna osobowość Hitlera jest najlepszym przykładem doprowadzenia do skrajnych konsekwencji zaleceń, jakie formułował Machiavelli w swoim Księciu. Ale jak wskazywali Karl Jaspers i Hannah Arendt, swiat pozbawiony transcendencji, skierowany na realizację interesów materialnych i indywidualnych przyjemności, wytwarza dogodne podglebie dla patologii ducha, która przejawia się w różnych formach w sferze społecznej, infekujac nie tylko masy, ale również elity, które ulegając gnostyckiej wizji, daża zawsze do katastrofy. Antidotum na szaleństwa i terror dwudziestowiecznych totalitaryzmów dostrzega Piekarski w odnowieniu teologii politycznej, czyli przywró- 
ceniu równowagi pomiędzy wiarą a rozumem w kulturze. Apelowali o to w XX wieku Leo Strauss i Eric Voegelin, dostrzegajac w dwóch głównych filarach cywilizacji zachodniej, jakimi sa dziedzictwo Aten i Jerozolimy, niezbędny element uniwersalności, chroniący rozum przed nowożytna deformacja, będąca wynikiem zamachu na sacrum w imię sekularyzacji. Dodajmy tylko, że modny ostatnio w Polsce francuski zwolennik Straussa - Rémi Brague proponuje w książce Europa. Droga rzymska, trzeci filar Zachodu, którym jest rzymskie chrześcijaństwo. Być może nie tylko odnowa teologii politycznej, ale również ożywczych źródeł duchowości europejskiej powinna się dokonać - jak namawia nas Brague - poprzez głęboka odnowę katolickich zasad i wartości.

Część czwarta omawianej książki nosi tytuł Filozof w polis i kontynuuje pewne zagadnienia $z$ części trzeciej. Piekarski powraca do analizy faszyzmu w kontekście winy i odpowiedzialności elit intelektualnych oraz pisze o nikczemności polityki w dobie społeczeństwa masowego. Nie skupia się przy tym na motywach indywidualnych i psychologicznych, które Mark Lilla nazywa „lekkomyślnościa umysłu", lecz szuka uwarunkowań strukturalnych, ideologicznych i politycznych. Ciekawsze sa jednak te teksty, w których omawia rolę i zadanie filozofa w społeczeństwie na przykładzie MacIntyre'a, Webera i Straussa. Stwierdza, że pozytywistyczna koncepcja nauk politycznych i społecznych, postulująca neutralność aksjologiczną, pozbawia intelektualistów wszelkiej broni w starciu $z$ barbarzyństwem i filisterstwem. Dlatego filozof ma obowiązek prowadzić dociekania moralne w trosce o dobro wspólne i nieideologiczne funkcjonowanie instytucji politycznych i społecznych. Zdaniem Piekarskiego, najlepsza, a może nawet jedyna perspektywa jest klasyczna tradycja roztropności nawiąująca do koncepcji prawa naturalnego. Daje ona stabilna i nierelatywistyczna podstawę do uformowania wzorca racjonalnej debaty, w której pojęta po arystotelesowsku retoryka filozoficzna staje się sztuką dyskutowania, wykraczająca poza zwykła dialektykę i sofistykę i szukająca podstaw argumentacji w duchu odpowiedzialności za żywotność i dobro ludzkiej wspólnoty. 
W ostatniej części książki autor omawia problemy i wyzwania globalizacji oraz szuka alternatywy politycznej dla zglobalizowanego świata. Wychodzi od rozważenia kwestii wojny sprawiedliwej w kontekście światowego państwa prawa i projektu wiecznego pokoju. Stwierdza jednak, że tworzenie różnego rodzaju organizacji międzynarodowych, a nawet propozycja państwa globalnego, zmierza bardziej do kontroli nad strategicznymi surowcami na świecie, co rodzi nowe formy chaosu, nad którymi zapanować może jakieś superpaństwo, kojarzone bardziej $z$ dominacja i władzą imperialistyczna, niż światowy rząd globalny, będący dopełnieniem projektu oświeceniowego. Toteż uniwersalistyczne obietnice globalizacji, niosace nadzieję na dobrobyt i bezpieczeństwo, moga owocować nowymi formami reakcji obronnych, przejawiajacymi sie $\mathrm{w}$ działaniach terrorystycznych, a nawet ludobójczych, w obronie suwerenności. Ponadto, jak stwierdza Piekarski, nowy porzadek świata i społeczeństwo globalne, które obiecuje perspektywa globalizacyjna, może wytworzyć tylko jakąś niższą formę społeczeństwa masowych konsumentów, zrozumiałego jedynie w kategoriach biologicznych lub quasi-ekonomicznych. Jego sceptycyzm wobec jakiejś jednej formy władzy i parlamentu światowego bierze się głównie $z$ przekonania, że wspólnotą najwyższego rzędu jest cywilizacja. Odwołuje się przy tym do koncepcji cywilizacji zaproponowanej przez Feliksa Konecznego, który podkreślał wyraźnie, że nie można być cywilizowanym na więcej niż jeden sposób. Toteż nie ma możliwości zainicjowania żadnej instytucji ogólnoświatowej, która byłaby możliwa dla wszystkich, bo w praktyce musiałoby to oznaczać ucywilizowanie społeczeństwa światowego w jakiś konkretny sposób. Jeżeli zatem chcemy zrozumieć dzisiejsze konflikty światowe powstające na styku cywilizacji, to musimy wziąc pod uwagę, że są one przynajmniej po części skutkiem reakcji na proces uniwersalizacyjnych zapędów ideologii globalizacji. Piekarski nie poprzestaje jednak na diagnozie, lecz proponuje również rozwiąanie alternatywne. Dostrzega je w klasycznej koncepcji republikańskiej, opartej na idei wolności indywidualnej. Tradycja ta ma źródła w koncepcjach republikań- 
skiego Rzymu z okresu Cycerona i Salustiusza. Opowiada się za państwem republikańskim, czyli wspólnotą wolnych obywateli, kierowanych przez władzę wybierana $\mathrm{w}$ wolnych wyborach na czas określony i sprawowana dla dobra wspólnego. Narzędziem obrony wolności i sprawiedliwości sa $\mathrm{w}$ tej koncepcji silne państwa, a nie jakaś instytucja ogólnoświatowa. Co więcej, rządzący republika to ludzie prawi, dżentelmeni posiadający virtus, sprawujący władzę dla dobra obywateli. Nasz autor, idąc za przekonaniami Ryszarda Legutki i Zdzisława Krasnodębskiego, dostrzega, że na gruncie polskim tradycję republikańska można płynnie połączyć $z$ rodzima tradycja chrześcijańska. Byłby to przekonujacy wyraz owej „drogi rzymskiej" jednoczącej w jakiejś twórczej syntezie najbardziej inspirujace elementy tradycji zachodniej, płynace $z$ dziedzictwa greckiego i hebrajskiego, $z$ Aten i Jerozolimy.

Podsumowując, dopowiedzmy, że książka Piekarskiego jest napisana dobrym stylem, który przynosi radość z czytania. Autor filozofuje o sprawach politycznych $\mathrm{w}$ szerokim kontekście krytycznym. Jest to przy tym filozofowanie zawsze $z$ klasykami, opowiadające się za silną koncepcja moralnego charakteru polityki. Autor nie stroni przy tym od dydaktyzmu i silnego zaangażowania moralnego. Dlatego często ostrzega i wychowuje, stoi na straży moralności publicznej i sprawiedliwości politycznej. $Z$ drugiej strony namawia do roztropności i rozumności w ocenie polityki i życia publicznego. Jest jak klasyczny dżentelmen, który ceni prawdziwe cnoty, a nie podróbki proponowane przez Machiavellego. Czytelnik, który sięgnie po tę książkę, spojrzy na wiele spraw dzisiejszej filozofii i polityki $z$ nowej perspektywy. Lektura tej książki zarówno sprawi mnóstwo przyjemności, jak i dostarczy wielu inspiracji.

Ryszard Mordarski

Ryszard Mordarski - doktor habilitowany, profesor Uniwersytetu Kazimierza Wielkiego w Bydgoszczy. 